FRANCIS J. BRESLIN

Oxford, New Jersey

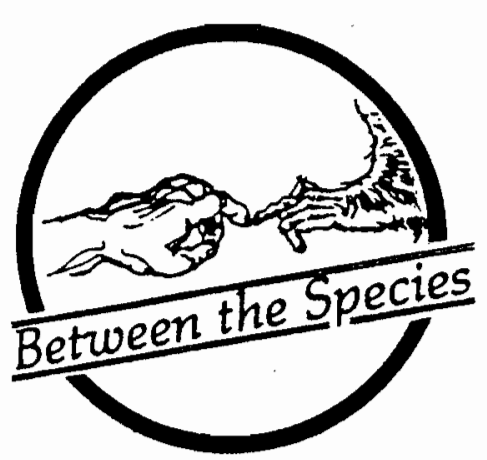

They had been observing the Earth often of late. The human beings were growing in numbers. There would soon be no food for everyone, just hunger, misery, and gradual death. Already it was happening. In the struggle with life, many lay dying.

They had observed this for years and finally resolved to end the untold distress. They would thin out the herd by harvesting it.

An expedition was thus sent out. Each squadron would encircle a populous area, land along the periphery, set down its crews, which would converge toward the center. Markers 'would bring up the rear, choosing those carcasses most fit for consumption.

Across the Earth, the scene was the same: some humans resisting with primitive weapons; others just trembling, awaiting their end. Thousands of humans were thereby dispatched. In three days it was over, and the spaceships were gone.

As the ships sped homewards, their crews rejoiced in what they had done. They were fate's special envoys dispensing mercy and averting cruel death. No more need humans die from starvation, no longer succumb in the struggle with life. They were spared this now. They had been shown a kindness seldom bestowed.

The survivors sought meaning in what had occurred. But such was their vision that they could not discern the Larger Plan. For, had they seen it, they would have been grateful in knowing that they had been saved from themselves.

Observing the Earth in later years, they noted the humans again growing in numbers. A second expedition was therefore sent out, needed, it was said, to avert cruel death. Before long, other expeditions followed--the humans' struggle to save their lives was becoming sport to the harvesters. The stalk of the prey, the thrill of the chase, the blind instincts of primitive beasts against the civilized refinements of superior beings-these were the joys which were eagerly sought. For when the two finally met, the one firing his weapon, the other thrown to the ground, at that moment of gazing into the human's eyes, as it thrashed about and twisted in pain, at that monent of ecstasy, the hours of toil were redeemed and forgotten, for now the prey lay dead at his feet.

Soon protest arose. Many could not grasp how one took pleasure from this sort of thing, or indeed, what sort of pleasure it actually was. The harvesters, for their part, could not comprehend why they were misjudged. Had they not saved the herd from cruel death? Did humans have a value unto themselves? Were they more than a crop ripe for the harvest?

Ramox was a veteran of many expeditions and relished their pleasures. He had heard the protest and dismissed it as foolish. He continued to harvest until, one day, he came upon a curious scene. He was part of a group pursuing two humans. As the group drew nearer, they saw a male and fernale running with interlocked hands. The air was cut by a beam of light, and the female fell dead. The male lost his balance, picked himself up, was about to continue when, looking for the female, he saw what had happened. Forgetting his pursuers, he slowly knelt beside his fallen companion, and gathering her up within his arms, pressed her closely to himself and wept. There was a very Iong silence. The air was pierced by a second beam, and he too fell dead.

Ramox witnessed this and turned away slowly. he wandered aimlessly until, coming upon a lonely forest, he entered it and 
walked a great distance. Gradually he grew weak and collapsed to the ground.

He areant he was a human being, running frantically to save his life. The dread of extinction was in his mouth. They were gaining on him, and there was no escape. Never again would he walk the earth, never again hold those whom he loved. They were almost upon him when suddenly he felt an unbearable pain. The beam of light had found its maxk.

Then he sensed a nysterious presence, and a voice was heard which engulfed his soul: "You now begin to see with the heart. We are all of us creatures in the abyss of this world. We are here for a moment and then are no more. Death and oblivion await us all. But even while we are here, no matter what our place on creation's scale, we are all of us assailed by pain. Pain is life's Dumb Brute. It does not see life's beauty or brevity. It sees only its victim whom it wants to destroy. We are as one with every creature--the weak, the lowly, the helpless--sharing its fate. Pain unites us and makes us one. In this harsh, dark night, how can we see pain and not be saddened? How can we cause it and not feel shane?"

Ramox awoke. Lying there numbly, he stared at the heavens. Then he arose and made his way back to the awaiting ships. As he walked, he could see the markers busy at work.

At home, Ramox soon began to protest. The voice in his dream would give him no peace. Inflicting pain, however artfully disguised by words, was nothing else but. inflicting pain, a strange sort of pleasure, and one which left the self befouled.

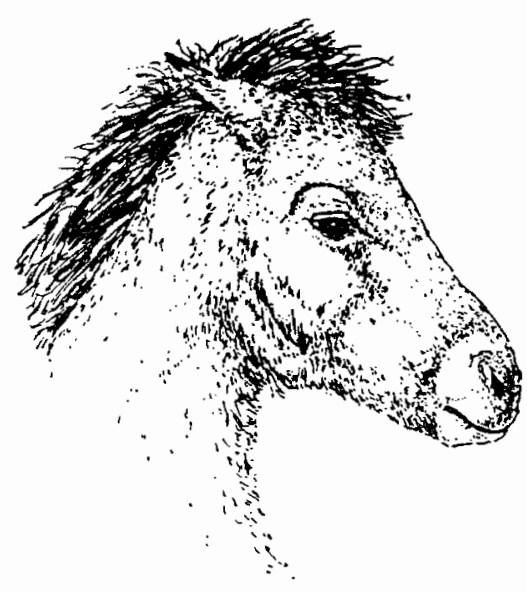

\section{THE SACRED PAW: THE BEAR IN NATURE, MYTH AND LITERATURE}

\author{
BY PAUL SHEPARD and BARRY SANDERS
}

Reviewed by
ELIZABETH A. LAWRENCE Tufts University

For the growing numbers of people who are concerned with the relationship with nature, and for inspiring those who should be, The Sacred Paw is an important book. Drawing upon data about bears from many disciplines, the authors provide the vital perspective needed in today's fast-paced and often fragmented world, for their approach to their subject is holistic. Shepard and Sanders have demonstrated how one particular animal is not just a biological entity (though interesting enough on those terms), but rather represents the sum total of diverse concepts about its species in the human consciousness. The reader learns that beliefs about bears, and the symbolic meaning with which the animals are imbued in folklore, mythology, and literature, determine, even as they are determined by, human interaction with living animals.

Even though relatively few people in modern times may have contact with actual bears, the authors point out that many concepts related to these once-abundant animals have penetrated into human thought processes and thereby have become relevant to everyday life. Beginning early in American history, the bear has been especially significant, looming large in frontier consciousness both as a symbol and a real denizen of the wilderness. And throughout the world, from prehistoric times, evidence indicates that wherever the bear has ranged, it has generally been looked upon by those societies living in or near its domain as the most majestic of animals, inspiring fear and awe as well as respect and adniration. Somewhat paradoxically, the bear has been viewed as the epitome

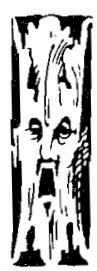

REVIEW

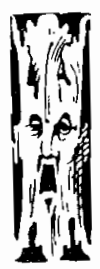

